\title{
Origin and Evolution of Medical Journals Related to the Medical Faculty of Universidad Autónoma de Nuevo León
}

\author{
Carlos E. Medina-De la Garza ${ }^{1,2}$ and María de los A. Castro-Corona ${ }^{1,2}$ \\ ${ }^{1}$ Department of Immunology, “Dr. José Eleuterio González” University Hospital; ²Centro de Investigación y Desarrollo en Ciencias de la Salud (Center \\ for Research and Development in Health Sciences, CIDICS. Universidad Autónoma de Nuevo León, Monterrey, Mexico
}

\begin{abstract}
We reviewed the medical journals related to the Faculty of Medicine of Universidad Autónoma de Nuevo León in Monterrey, Mexico, throughout its history. The first journal (El Escolar Médico) started in March 1888 and the last and current journal (Medicina Universitaria) started in October 1998. We could identify nine medical journals in a 130-year period (1888-2018) and four departmental Bulletins. There are a number of journals which are known or suspected to have existed, but could not be located so far. The outreach and institutional value of these journals are briefly discussed.
\end{abstract}

Key words: Medical Journals. History. Monterrey. UANL.

"...I do understand the effort it takes, editing a work of this nature in our region"

Medicina Universitaria, letters to the editor, $1970^{1}$

\section{Introduction}

Teaching of medicine in Monterrey, Mexico, started with Pascual Constanza in 1829 and was formalized by José Eleuterio González with the School of Medicine of Monterrey foundation in 1859. The school, closed due to financial problems in 1902 and reopened in 1912 as the School of Medicine of Nuevo Leon, became the cornerstone for the actual Faculty of Medicine at Universidad Autónoma de Nuevo León ${ }^{2}$. Since its first foundation, the school hosted among its alumni and professors those with proper spirit and skills to promote medical knowledge through books and periodicals. Thus, editorial work related to our institution began in the late $19^{\text {th }}$ century and continued to this day. To acknowledge these past and present efforts, this document summarizes the origin, path, and evolution of the periodical journals which have been published during the last 16 decades of medical academic presence of our school. Moreover, we refer herein to some publications edited by medical organizations whose editors and board members were prominent faculty members. Being also a part of the academia, they had an intellectual, operational, and scholar commitment which linked the institution to their journals. This is a brief historical summary of the journals related to our Faculty of Medicine.

\section{El Escolar Médico (The Medical Scholar)}

Described as "a newspaper dedicated solely to medical sciences" (Fig. 1) and redacted by students of the School of Medicine of Monterrey, El Escolar Médico's first issue appeared on March 15, 1888.

On its second number, issued in April, the newspaper published the sad news of José Eleuterio González's passing on the $4^{\text {th }}$ of that month, as well as the panegyric pronounced by José María Lozano.

\section{Correspondence:}

Carlos E. Medina-De la Garza

E-mail: carlos.medina@uanl.mx
Date of reception: 29-01-2018

Date of acceptance: 29-01-2018

DOI: 10.24875/RMU.M18000008
Available online: $30-05-2018$ Medicina Universitaria. 2018;20(1):58-65 www.medicinauniversitaria.org

(1) 2018 Universidad Autónoma de Nuevo León. Published by Permanyer México SA de CV. This is an open access article under the CC BY-NC-ND license (http://creativecommons.org/licenses/by-nc-nd/4.0/). 


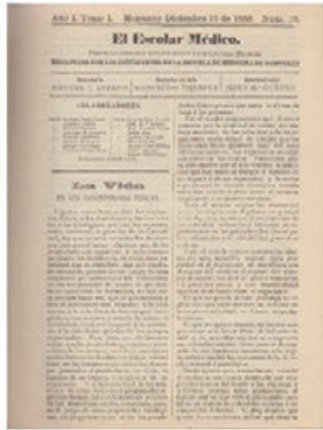

El Escolar Médico, 1888

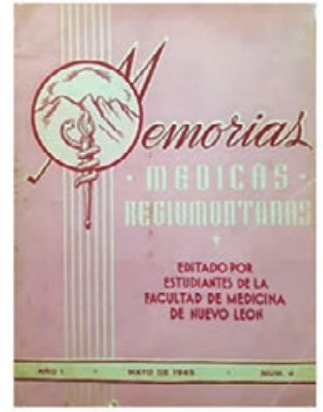

Memorias Médicas Regiomontanas, 1944

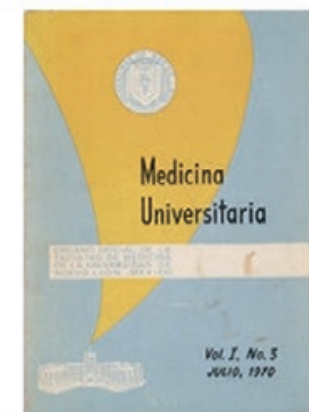

Medicina Universitaria, 1970

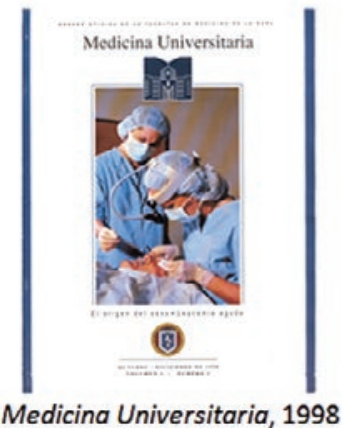

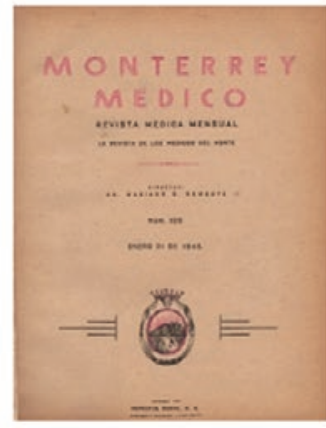

Monterrey Médico, 1936

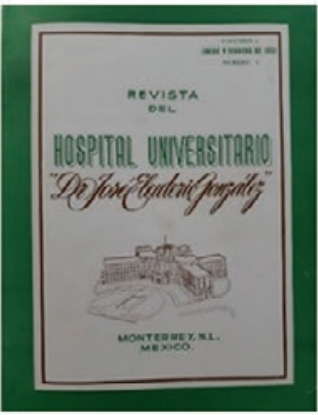

Revista del Hospital Universitario "Dr. José Eleuterio González", 1951.

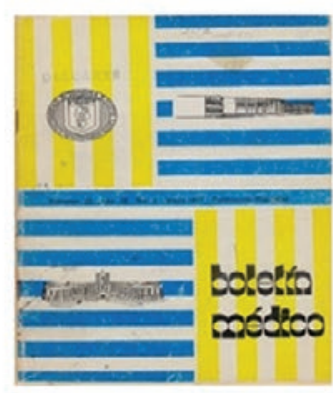

Boletin Médico, 1974

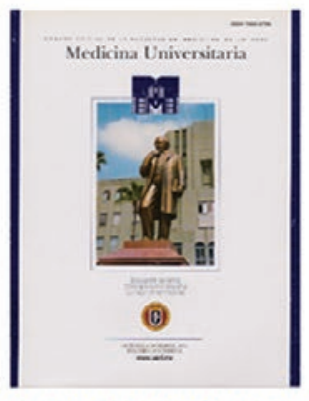

Medicina Universitaria, 2003

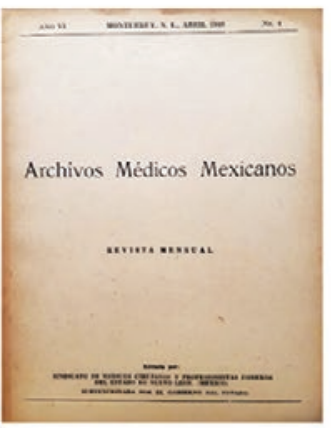

Archivos Médicos Mexicanos, 1943

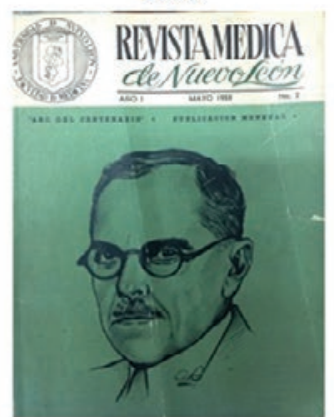

Revista Médica de Nuevo León, 1959

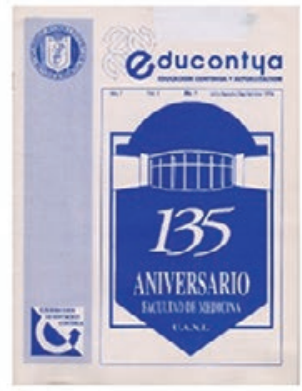

EDUCONTYA, 1994

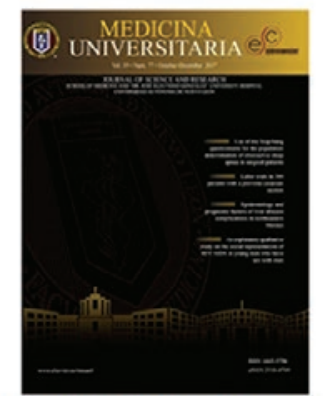

Medicina Universitaria, 2017

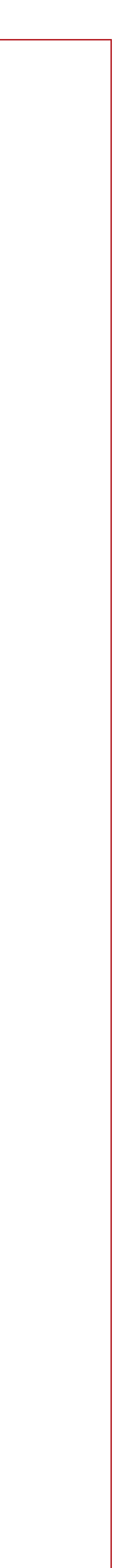

Figure 1. Covers of different publications over the years

El Escolar Médico published reviews on topics of interest, articles about therapeutic notes, school rules, and announcements, as well as necrological notes. The inaugural thesis of Rafael Garza Cantú, "Psychophysics - An influence of the moral over the organic and reciprocally from the organic to the moral 
within the human species," was serialized and published in the newspaper.

The staff included editor-in-chief and founder Manuel Manfredo Tijerina, secretary Manuel J. Lozano, and administrator Jesús María Guerra. The physician Manuel Pérez Bibbins, also a playwright, writer, and cofounder of the famous political satirical magazine " $E I$ Hijo del Ahuizote" (The son of the Ahuizote), was a prominent contributor. With an unknown print run, the last issue printed was in January 1889 (erroneously marked as 1888). El Escolar Médico was the pioneer medical periodical in Monterrey².

\section{Monterrey Médico (Medical Monterrey)}

Journal founded in 1936 by the Spanish radiologist and radiotherapist Mariano García Somonte. Monterrey Médico (Fig. 1) was a monthly publication and did not belong to the school, as it was self-proclaimed "the journal of northern physicians." This journal had Somonte as director, José Iglesias $G$. as vice-director, and Enrique V. Santos, Guillermo Benavides Uribe, Juan Alanís Ochoa, and Roberto Treviño Martínez as editors, all of them, including G. Somonte, were renowned university lecturers. Treviño Martínez stands out among them, for he was Dean of the School (1947-48), and in this position, he founded the Escuela de Técnicos de Laboratorio (Laboratory Technician School) and started the works for the construction of new buildings for the medical school. On the other side, G. Somonte founded in Monterrey the Instituto de Radioterapia Curie (Curie Institute of Radiotherapy). He was an outstanding writer with diverse literary and journalistic activities and a number of published books. He wrote editorials and stories for the local newspaper "El Porvenir."

This journal was last published in 1946 and its contents included original articles, treatment guidelines, and reviews of world medical literature. It was listed in the WHO/UNESCO's World Medical Periodicals, under the short name of Monterrey méd ${ }^{3}$.

\section{Archivos Médicos Mexicanos (Mexican Medical Archives)}

A monthly journal published by the "Sindicato de Médicos Cirujanos y Profesionistas Conexos del Estado de Nuevo León" (Union of Physicians - Surgeons and Associated Professionals of the State of Nuevo León). Archivos (Fig. 1) began in May 1943, and its opening editorial stated: "...it is born with the purpose of stimulating scientific production in Mexico and open wide its pages to it..." Dante Decanini Flores was the founding president, alongside the Spanish pediatrician Aurelio Romeo Lozano, cofounder of the journal Archivos Pediátricos Españoles (Spanish Pediatric Archives), Ángel Martínez Villarreal, who was at that time Dean of the School of Medicine, and pediatrics professor Telésforo Chapa. Later on, its editorial board added professors such as the renowned Spanish otolaryngologist Luis Fumagallo Pérez, surgery professor and future Rector of the University of Nuevo León Colonel Arnulfo Treviño Garza, cardiologist Enrique Carlos Livas who was also Rector of the University (1943-1948), and Francisco Vela González, Director of the Civil Hospital (1944-49), who interestingly, appears in the journal pages, in the forties already, as "Director of the University Hospital."

Archives published original articles, reviews of world medical literature, and summaries. The commemorative book Memoirs of the School of Medicine (1952) edited by Professor Martín Torres, considered Archives an institutional publication ${ }^{4}$. It was included in the World Medical Periodicals with the abbreviation Arch. med. Mex. ${ }^{3}$ and was last printed in 1956.

\section{Memorias Médicas Regiomontanas (Monterrey's Medical Memoirs)}

Journal founded and "...edited by students of the Faculty of Medicine of Nuevo Leon" (Fig. 1). It started in November of 1944 and was published on a bimonthly basis. At its birth, there was no official journat in the faculty. Chronologically, Memorias coincided with the Boletin published by the Institute of Scientific Research of the University of Nuevo León, which was a different facility devoted to natural sciences in a broader sense. Memorias was published for at least 2 years, and as it started, the Dean of the Faculty was Ángel Martínez Villarreal, a surgeon who was an advocate to tie the Civil Hospital to the faculty and turn it into a teaching facility. The journal's directory shows the names of participants without titles, thus indicating their student status. Gustavo Alvarado Ortiz was editorial director, Rafael S. Villarreal was manager, and Edmundo Mendoza, Adrián Quirós, and Sergio De la Garza were editorial assistants. The latter stands out and after his graduate studies would become professor and later on Head of Pathology at the faculty, and also Head of Graduate Programs 5 .

Memorias published original works, reviews, and information about lectures given at the then Civil Hospital, where medical students did internships from the 
$4^{\text {th }}$ to $6^{\text {th }}$ years of medical career program ${ }^{5}$. The print run of Memorias is unknown.

\section{Revista del Hospital Universitario "Dr. José Eleuterio González" (Journal of "Dr. José Eleuterio González" University Hospital)}

This bimonthly journal began in January 1951 (Fig. 1), as Serapio Muraira Muraira was Dean of the Faculty. The Civil Hospital acquired the status of University Hospital during his deanship. The transition was formalized by the State Government decree of June 2, 1952. Therefore, the Dean of the Faculty would take over the leadership of the now University Hospital ${ }^{2}$. However, in 1951, a bit before the above-mentioned decree, the journal title already bore the name of University Hospital on it, which revealed an explicit academic link and an increased clinical orientation of the Faculty.

Muraira's first editorial read "...the two fundamental designs of this journal: to mark footprints and disseminate concepts... be a true reflection of our hospital environment... and of the medical world of Monterrey..." In addition to Serapio Muraira Muraira as founding director, Gustavo Alvarado Ortiz was managing director, Sergio De la Garza editor, and Humberto Ruiz Schubert managing editor. As editorial board, the whole "body of professors of the Faculty of Medicine of the University of Nuevo Leon." Professors Alvarado and De la Garza had already participated as students in the edition of Memorias Médicas. Later on, De la Garza served as director of the Revista and remained in that appointment until the end of the journal. The Revista was last printed in 1962.

\section{Revista Médica de Nuevo León (Medical Journal of Nuevo Leon)}

This monthly journal began in April 1959, as Mentor Tijerina was Dean of the Faculty. That was the year of "Centennial of Foundation" celebration. The journal was thus concurrent to Revista del Hospital Universitario and, just like the Escolar Médico and Memorias Médicas, it was edited by students advised by professors. The cover of the first issue showed a portrait of founder José Eleuterio González. The second issue showed a portrait of Eusebio Guajardo (Fig. 1) who, among other achievements, prevented a second close of the school in 1921, and the third issue a portrait of Angel Martinez Villareal, mastermind for establishing a sui generis teaching hospital model. These portraits of outstanding men in the history of the School/Faculty on the cover page of Revista Médica were sketched by Alfonso Reyes Aurrecoechea. The first issue provided the listing and description of activities and programmed events for the Centennial. Director of Revista Médica was Raúl Calderón with collaboration of Antonio Díaz, Luis Muñoz, Francisco Puente, Indalecio Sánchez, and Gilberto Muñoz Reyes as editors and administrators. The journal had two sections: a scientific, where original articles, reviews, and updates were published, and a cultural section with biographical sketches of the outstanding individuals related to the school, literary notes, and even artistic reproductions on translucent paper. The print run of this journal is unknown and it was published only from April until the celebration in October. It is estimated there were 6-7 issues; the accurate number of issues edited is unknown.

\section{Medicina Universitaria (University Medicine)}

This journal was conceived by a group of professors, who realized again the need for a vehicle for expression of medical knowledge created at the faculty (Eig. 1). The professors founded the journal and chose Álvaro Gómez Leal as editor. The journal started under Ángel Martínez Maldonado as director of faculty and hospital. Editorial board was composed by Manuel Rodríguez Quintanilla, Rodrigo F. Barragán Villarreal, Ricardo Rangel Guerra, José Morales Casas, Alfredo Delgado Arredondo, and Fernando Ovalle Berumen. The vicedean office for graduate studies was responsible for editing, printing, and handling. With a circulation of 5000 copies, Medicina was distributed directly among professors and students of the faculty and hospital, and also sent to other institutions. Medicina Universitaria was published in four issues from January to December 1970. An early setback in its publication was access to original material and manuscripts, which may have contributed to the short live of the journal (Rangel Guerra, R., personal communication, 2016). Scarce resources and the serious political issues at that time were among the main reasons ${ }^{6}$ to stop its printing after one year.

\section{Boletín Médico (Medical Bulletin)}

Bimonthly publication, subtitled "Official Organ of the Faculty of Medicine of Autonomous University of Nuevo Leon" (Fig. 1), started in 1974. It was initially directed 
by Roberto C. Villarreal (Villarreal CR, personal communication, 2016) and the editorial board formed by Leonel Rodríguez, Lorenzo Valle, Jesús Cruz Valdez, and José Manuel Pérez Morales. Later on, Pérez Morales directed the bulletin, and Julio Scheib Garza, Luis García Betancourt, and Baltasar Rodríguez Treviño joined. The bulletin was published by the office of vicedean for graduate studies and was distributed free of charge among professors, students, and other institutions. It featured editorials, original articles, clinical reviews, and a section on clinical cases. The Boletín was the current journal of faculty and hospital as the latter reached its $25^{\text {th }}$ anniversary as part of the university. Thus, it published the most relevant speeches of this celebration in the June 1977 issue: those of Dean and Hospital Director Fernando Ovalle Berumen (...the success of this institution... has not been due to rooms or equipment contained within... but... to staff and workers of all levels and categories) and the speech by the renowned guest Ignacio Chávez Sánchez (...the social demand for a University Hospital is a double task that supplement each other: to serve as Hospital to protect life of sick people and be a school where higher medical values are taught...). The number of copies printed is unknown, and its publication ended in 1978.

\section{EDUCONTyA (Educación Continua y Actualización - Continuous Education and Update)}

A quarterly journal that began in July-September 1994 , before celebration of the $135^{\text {th }}$ anniversary of the faculty, under Dean Jesús Zacarías Villarreal Pérez (Fig. 1). It was created by the office of vice-dean for continuous education, with its holder Nancy Estela Fernández Garza as editor and Carlos De la Garza González, Miguel Hinojosa Lezama, Miguel Reyes Amezcua, Angélica Romero de León, and Rita Elsa Rositas as editorial board. The goal of EDUCONTyA as its name announced was to provide alumni and health professionals with an updated platform through original articles, reviews, and clinical cases, oriented toward common diseases and with emphasis on the first level of medical care. In their own words, EDUCONTyA was not intended to substitute specialized sources, and was composed of articles and reviews from faculty and hospital professors to provide readers with supplementary information and updates on clinical and academic issues. Its initial print run was 2000 copies. The journal ceased publication in 1997.

\section{Medicina Universitaria (University Medicine) second-run}

In 1998, Jesús Áncer Rodriguez was Dean of Faculty and Hospital and Dionicio Galarza Delgado Vice-Dean for Continuous Education. The latter proposed the creation of a journal to consolidate previous editorial efforts and establish an enduring journal. It was agreed to name it Medicina Universitaria again, (Fig. 1) and was set to be printed in October of that year in its second run, with David Gómez Almaguer as editor-in-chief. The editorial committee was composed by 19 faculty professors. With a print run of 1000 copies, it was initially published by Nieto Editores and from 2011 by Elsevier.

It was the first faculty journal to bear an ISSN (International Standard Serial Number). Medicina Universitaria was also integrated into Elsevier's consolidated system for handling of manuscripts and peer review (EES) and belonged to Science Direct platform until December 2017. From January 2018 on, publication of Medicina Universitaria shifted to management and technical edition by Permanyer, a medical publishing house from Barcelona.

Medicina Universitaria publishes its entire contents in English with a broad range of articles: originals, reviews, history and philosophy of medicine, opinion articles, and expert guidelines. Currently available through open access, it is the longest-running journal of the faculty published by an external editor. Currently, the journal is under review and evaluation by the $\mathrm{Na}$ tional Library of Medicine (USA) for its acceptance in the MEDLINE database through PubMed.

\section{Other Journals and Departmental Bulletins (Fig. 2)}

La Gaceta (The Gazette), a bimonthly departmental journal, started in January-February 1978 as "informative organ of the Department of Preventive Medicine." Editor was Department's Head Francisco González Rodríguez, supported by Heriberto Mora Zepeda and other staff. It dealt with local epidemiological issues, history of medicine, and practical advice for students. Technical edition of La Gaceta was made in the printing department of the university. The print run is unknown.

MEDinforma (MEDinform) was a bulletin published from 1993 to 1995 by the Office for Research and Postgraduate Studies under Roberto Mercado Longoria leadership and edited by Oscar De la Garza Castro and later on by Diego García Compeán. It published news from the office, notes on clinical and diagnostic issues and updates on 


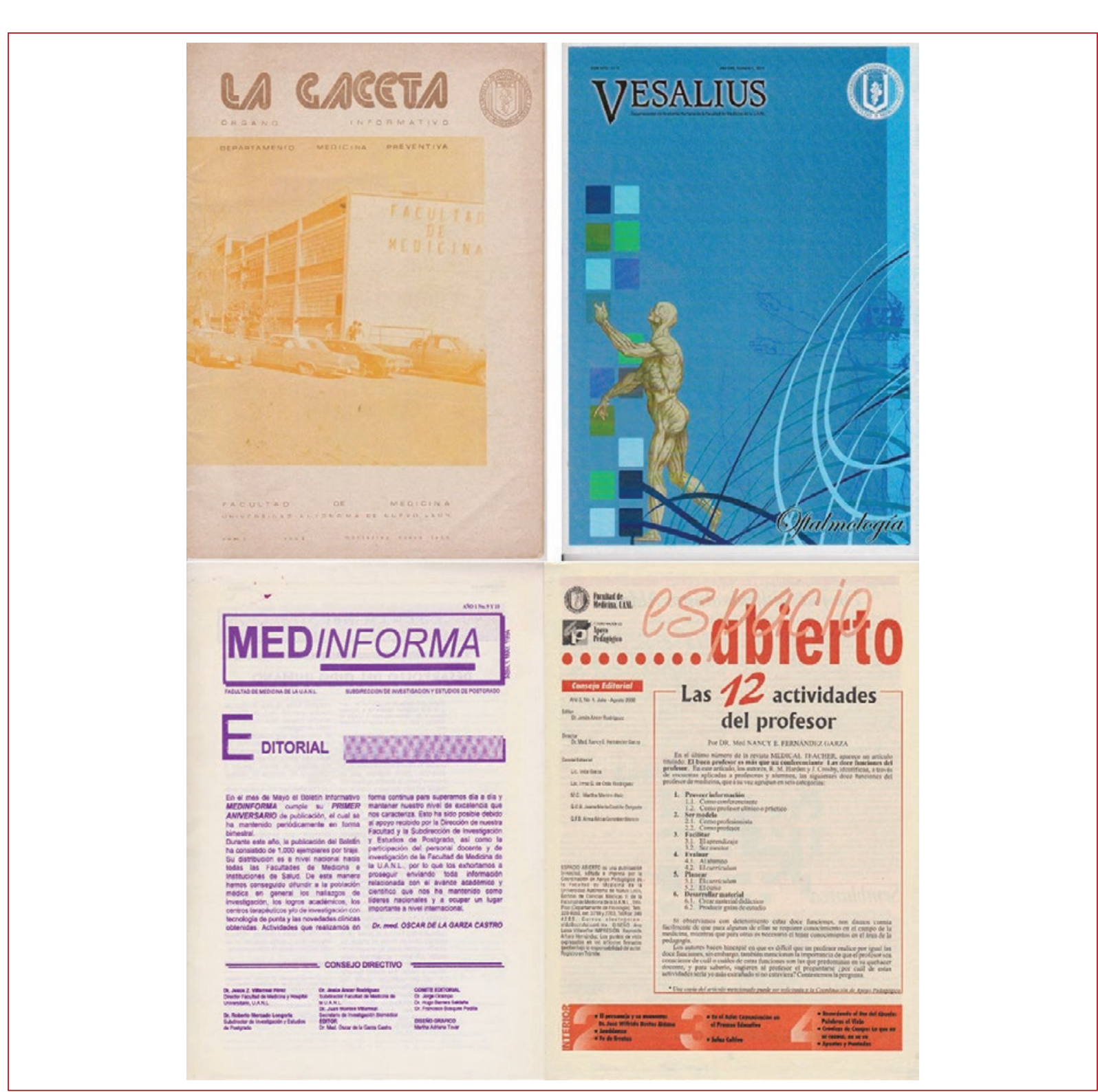

Figure 2. Departmental Bulletins. From top left clockwise: La Gaceta (the Gazette), Vesalius, Espacio Abierto (Open Space) and MEDInforma.

therapeutics, along with information regarding the "Biomedical Research Congress," which started its positioning as the main medical research event of the institution.

Vesalius, from the Department of Anatomy, began as a bimonthly bulletin in January 1995, established by Ramiro Montemayor Martínez as director and Catarino Rodríguez Torres as editor. It evolved into a journal format under direction of Santos Guzmán López and edition of Rodrigo Elizondo Omaña. It presents editorials, historical notes, semiology with anatomical correlation, and clinical cases. It is currently published by the department in electronic version.
Espacio Abierto (Open Space) was a bimonthly newsletter published by Pedagogical Support Office of the faculty from 1997 to 2001, with Nancy Fernández Garza as editor and a committee formed by female professors from various departments from the faculty and hospital.

\section{Journals with evidence of having once existed}

The Journal of Biology and Medicine (year of publication unknown) no longer exists in the libraries of the Universidad Autónoma de Nuevo León (UANL), nor 


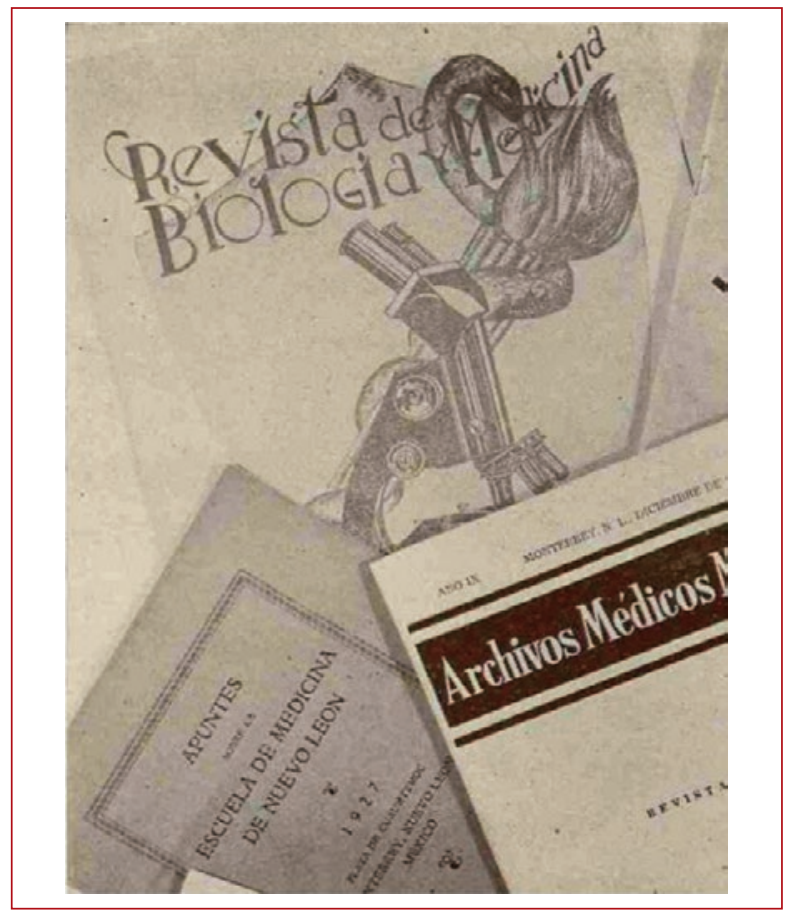

Figure 3. Two misplaced publications: Revista de Biología y Medicina (Biology and Medicine Journal, year unknown) and Apuntes sobre la Escuela de Medicina de Nuevo León (1927).

other libraries and databases consulted. The only evidence so far about this journal was found in a photocomposition published in Faculty of Medicine, Memoirs ${ }^{4}$ in the section corresponding to "Publications" (Fig. 3). We speculate this journal may have been published starting somewhere in the 1930s, a time when no journal entirely from the school was published.

Interestingly, in the same image, we can see the booklet "Apuntes Sobre la Escuela de Medicina de Nuevo León (Notes on the School of Medicine of Nuevo Leon - 1927)" which, based on its title, deals with the school reopened in 1912. However, details on the text or contents of this booklet are unknown. The booklet was not found in any libraries and databases consulted and its location to date remains unidentified. Eduardo Aguirre Pequeño, in his "Data regarding the School of Medicine of Monterrey" (1944) briefly cites this brochure ${ }^{7}$. We may also speculate that the latter publication by Aguirre Pequeño, which is of historical nature, may resemble in contents and/or to structure that from 1927. That Apuntes remains largely unrecognized is revealed by the fact that recent historical reviews by different authors do not mention or cite it within the institutional bibliography ${ }^{2,8-10}$.
An excerpt from the World Medical Periodicals of 1953 listed (exactly) 1000 periodicals in medicine and biology which published in Spanish ${ }^{3}$. Of these journals, 210 corresponded to Brazil (whose first language is naturally Portuguese), 207 to Argentina, 97 to Spain, 90 to Mexico, 74 to Cuba, 65 to Chile, 50 to Uruguay, and the remaining from other Latin American countries. Listed among Mexican journals were the Revista de Medicina y Cirugía (Journal of Medicine and Surgery - Rev. Med. Cirug., 1934?), published by the Sindicato Neoleonés de Médicos Cirujanos (Union of Physicians and Surgeons of the State of Nuevo Leon). In the forties, this union was headed by Francisco $\mathrm{L}$. Rocha ${ }^{10}$ renowned surgeon, professor of the school, and later Director of Civil Hospital (1941-1943). This journal has not been physically located in Mexico, and a single copy (volume 2, number 1) is cataloged at the website of the Historical Library and Wood Institute of the College of Physicians of Philadelphia, USA. This union journal was printed before another journal supported by a union, Archivos Médicos Mexicanos (see above) and indirect evidence suggests they may have been published concurrently in the 1940s.

Similarly, the journals Hospital (Hospital) and México Médico (Méx. Méd.) are cited in the aforementioned list as edited in Monterrey ${ }^{3}$, but we were unable so far to locate them. In the absence of physical evidence, the participation or work of professors of our faculty in these journals remains a matter of conjecture.

\section{Final comments and conclusion}

With the letter to the editor shown in the epigraph, Professor Oliverio Welsh Lozano described the difficulties, and the need to stimulate creativity, innovation, and scientific medical knowledge in our local medical environment in the 1970s. Since then, research and publication horizon in Monterrey has profoundly changed and evolved, with an ever-increasing scientific production in health sciences and biomedicine. As we reviewed in this page, this task originated with the edition of El Escolar Médico, a simple newspaper available in the $19^{\text {th }}$ century - Monterrey, continued in a number of different journals starting in the $30 \mathrm{~s}$ and $40 \mathrm{~s}$ of the $20^{\text {th }}$ century and still goes strong through Medicina Universitaria, a $21^{\text {st }}$ century journal accessible worldwide on the Internet. The medical editorial work of the UANL has evolved thanks to the effort, achievements, and ineluctable mistakes that were carried out in the construction, edition, and publishing of the different journals reviewed here. 
The creation and maintenance of a medical journal is an academically demanding pursuit and requires a permanent institutional effort and commitment. In our school and later on faculty, from 1888 to this day, a large number of characters, both students and professors, participated in this creative editorial task. It is important to note that in some journals, responsibility for assignment and operation fell mostly on students, who in turn continued this work as they became professors.

The documentary search for this work evidenced situations that we believe important to point out, such as the existence of forgotten, lost, or physically inaccessible publications, on which a specific search can be focused to confirm or rule out its existence. The research revealed that of the known and physically searchable journals, almost no complete collection exists, neither in institutional nor other local libraries.

The recognition of this deficit is a clear opportunity and may stimulate a tracking of such journals and bulletins in personal and private collections. Obtaining originals or copies of such historical material for the "Dr. Ángel Ulloa Gregori" museum hall of the Faculty of Medicine would be a significant contribution to the collective academic memory of our Alma Mater.

This historical exercise initiates the recognition of editorial activity in medicine carried out in the region by our school through a descriptive inventory. Knowing our medical journals and their evolution is a part of learning for the future, and also a current recognition to those who have participated in the development of this editorial work since 1888 .

As the educated mind of former Professor Martín Torres (1919-1988) expressed it "...it is the legitimate aspiration of the children of the School of Medicine to bring from the distance of the past, the immortal spark of fire that burnished the noblest consciences, and whose wise teachings. will be transmitted to future generations...".

\section{Acknowledgments}

We acknowledge the time and interest of many professors, among them the doctors Fernando Ovalle Berumen, Ricardo Salinas Ruiz, Ricardo Rangel Guerra, Francisco González Rodríguez, José Morales Casas, Alfredo Delgado Arredondo, Jesús Cruz Valdez, Dante Guerra Leal, Amador Flores Aréchiga, Román Garza Mercado, as well as Gilberto Muñoz Reyes, and Roberto Catarino Villarreal. To Ulrich Jiménez Herrera, Edmundo, and Alejandro Derbez García, Armando H. Ortiz, José Antonio Olvera, Juanita Cristerna, Verónica Gallegos and Reyna Vera from UANL and Maricarmen Olivares from the library of the National Institute of Cardiology, Mexico City, for hemerographic material.

\section{Dedication}

This article is dedicated to the memory of Emilio L. De la Garza De la Garza, a medical intern who died while performing his social service and of Sergio De la Garza Galván, a University professor who had a clear vision of what should be done and did it.

\section{References}

1. Welsh O. Cartas al Editor. Medicina Universitaria. Mexico: Elsevier; 1970, $1 ; 3$

2. Ortiz Guerrero AH. XIV Décadas de la Facultad de Medicina de la UANL. Medicina Universitaria; 2000. p. 2.

3. World Medical Periodicals/Periódicos Médicos del Mundo. WHO/Unesco. Citado en: Fishbein M y Pi-Sunyer J. Normas de Literatura Médica. México DF: La Prensa Medica Méxicana; 1954.

4. Torres Hernández M, editor. Memorias de la Facultad de Medicina. Monterrey; 1952.

5. Derbéz García E. Entrevista Con el Dr. Sergio de la Garza. México: Ciencia UANL; 2003. p. 14-22.

6. Gómez Almaguer D. Editorial: Medicina Universitaria; 1998. p.1, II.

7. Aguirre Pequeño E. Datos Para la Historia de la Escuela de Medicina de Monterrey. México: Publicaciones del Instituto de Investigaciones Científicas, UNL; 1944.

8. Salinas Cantú HP. Historia de la escuela de medicina de nuevo león. II. Educontya. 1994;2:25-6.

9. Sandoval Olvera JA. Papeles de Medicina. Reorganización del archivo histórico de la Facultad de Medicina. Memoria Universitaria; 2010;1:3-13.

10. Garza Mercado R. Destellos del Inicio de la Medicina en Monterrey. Parte Tres de Tres. Vol. 12. Nuevo León, México: La Facultad de Medicina de la Universidad Autónoma de Nuevo León y el Hospital Universitario Dr. José Eleuterio González (1813-1888) Medicina Universitaria; 2010. p. 64-9. 